\title{
Viewpoint \\ Human breast cancer stem cell markers CD44 and CD24: enriching for cells with functional properties in mice or in man? Christine Fillmore ${ }^{1}$ and Charlotte Kuperwasser ${ }^{2,3}$
}

\author{
1'Department of Genetics, Sackler School, Tufts University School of Medicine, Harrison Avenue, Boston, Massachusetts 02111, USA \\ ${ }^{2}$ Department of Anatomy \& Cellular Biology, Sackler School, Tufts University School of Medicine, Harrison Avenue, Boston, Massachusetts 02111, USA \\ ${ }^{3}$ Department of Radiation Oncology, Molecular Oncology Research Institute, Tufts-New England Medical Center, Boston, Massachusetts 02111, USA
}

Corresponding author: Charlotte Kuperwasser, Charlotte.Kuperwasser@tufts.edu

Published: 29 May 2007

This article is online at http://breast-cancer-research.com/content/9/3/303

(c) 2007 BioMed Central Ltd
Breast Cancer Research 2007, 9:303 (doi:10.1186/bcr1673)

cells that give rise to and maintain the bulk of the tumor mass. The use of Hoescht dye efflux, suspension sphere assays, and serial transplantation are all proposed methods for identifying and separating cancer stem cells from solid tumors. However, arguably the most effective method of identifying these cells, which may be morphologically indistinct from the bulk of the cancer, is through differential cell surface protein expression.

\section{The choice and relevance of solid tumor markers}

The relevance of current cancer stem cell markers for solid tumors remains controversial and perplexing. In leukemia, the rationale for using the cell surface makers CD $34^{+} / \mathrm{CD}_{3} 8^{-}$to identify LSCs was based on the known and shared markers for hematopoietic stem cells. However, in the case of breast cancer, the rationale for selection of prospective markers is less clear, primarily because the human breast stem cell has not yet been extensively characterized. Although a putative murine mammary stem cell was recently reported $[3,4]$, the markers used in these studies have yet to be applied to human breast cancer stem cells. More importantly, even if researchers do apply the mouse markers to human cells, lessons learned from the hematopoietic field would suggest that the markers in mouse may not translate to humans (for instance, CD38 and Sca1).

For solid tumors, the repertoire of cell surface markers currently used to identify human cancer stem cells includes CD44, CD133, epithelial surface antigen (ESA), and CD24, either singly or in combination. Specifically, the CD44+ phenotype is correlated positively with colon, breast, prostate, and pancreatic cancer initiator cells [2,5-7]. Likewise, $\mathrm{CD} 133^{+}$cells have been shown to initiate human glioblastoma, colon, prostate, and pancreatic cancers in mice

$\mathrm{ESA}=$ epithelial surface antigen; $\mathrm{LSC}=$ leukemia stem cell. 
[5-8]. The phenotype of pancreatic and breast cancer initiator cells and normal breast progenitor cells is $\operatorname{ESA}^{+}[2,7,9]$. Finally, CD24 has a more ambiguous past because it is positively correlated with tumorigenicity in pancreatic cancer [7] but negatively correlated in breast cancer [2], yet CD24+ cells are associated with invasive breast cancer [10].

The functional significance of these proteins is an area of investigation that remains poorly understood. It has been suggested that CD44 is an important molecule for metastasis because a nonmetastatic rat glioma cell line acquired metastatic properties when a splice variant of CD44 was ectopically over-expressed [11]. In addition, CD44 variant isoforms are differentially expressed during pregnancy and involution, indicating a role in normal breast epithelial homeostasis [12]. ESA is another molecule that deserves further investigation because it was shown to be essential for migration and invasion of the human breast cancer cell line MDA.MB.231 [13].

Regardless of the biologic activities of these markers, it is remarkable that the same cell surface markers enrich for tumor stem cells across many solid tumor types. Therefore, perhaps the markers that are currently used to identify 'stem cells' from solid tumors could actually be enriching for cells with certain functional properties in vivo or in vitro, namely to engraft successfully in mouse or to adhere and expand in culture. This theory is supported by the fact that nearly all studies on the prospective identification of human solid tumor stem cells have either xenografted the primary tumor into a nonobese diabetic/severe combined immunodeficient mouse, or briefly conditioned the tumor cells in culture before enriching for tumor initiating cells [2,5-7].

\section{What defines a cancer stem cell?}

The definition of a stem cell is the ability to self-renew and give rise to a daughter cell that is different from itself. The 'gold standard' in demonstrating stem cell activity is the ability to reconstitute a diverse tissue in vivo (normal or malignant). Although this is straightforward when studying murine stem cells, because the mouse serves as the natural host for engraftment studies, it is more complex when the only means for defining a human cancer stem cell is its ability to engraft in a mouse. Thus, if a cancer cell cannot successfully engraft into a mouse because of a species, hormonal, or microenvironment incompatibility, does this mean that the cell is not a cancer stem cell?

The importance of microenvironment was recently illustrated in an elegant study with leukemia [14]. In this study, murine LSCs deficient for CD44 introduced into the circulation of mice were unable to home to the bone marrow and thus could not form leukemia. However, the same CD44-deficient LSCs injected directly into the bone marrow were fully able to engraft and regenerate a heterogeneous tumor. Based on this work, it is clear that cancer stem cells that give rise to a heterogeneous tumor can exist, but if that same cell cannot engraft because of an incompatible microenvironment, should it no longer be defined as a cancer stem cell?

For human breast cancers, is it the case that CD44+/CD24 cells are simply better at engrafting in the mouse mammary microenvironment, or are they really more tumorigenic in the human setting? The murine mammary gland is an excellent site for transplantation of primary mouse mammary epithelial cells (normal and neoplastic) because it is the natural stromal microenvironment for murine mammary cells. However, attempts to introduce human mammary epithelial cells (normal or malignant) into mouse mammary fat pads were only successful when the fibrous stroma of the human breast was recreated [15-17]. Because the stromal cells that are adjacent to cancer cells can facilitate their engraftment and tumor formation $[16,18,19]$, it is plausible that CD44 ${ }^{+}$CD24 breast cancer cells are merely the cells that are the most successful in overcoming an engraftment incompatibility that exists when injecting human cells into the mouse adipose stroma.

\section{The relevance of CD44 and CD24 in human breast cancer}

Several studies that have attempted to repeat and expand on the $C D 44^{+} / C D 24$ - breast cancer initiator cell profile have thus far been inconclusive. In 2004, a clinical study reported that there was no statistically significant CD44 or CD24 staining in primary breast cancer sections in relation to tumor grade, type, or size [20]. The authors postulated that one difference is that they use primary sections, in which a pathologist can identify tumor tissue, whereas in their study Al-Hajj and coworkers [2] used cell sorting to remove Lincells and subsequent flow cytometry. However, two more recent reports $[21,22]$ have now confirmed, both in breast cancer derived cell lines and breast tumors, that CD44+/CD24- phenotypes are not necessarily associated with patient outcome or ability to metastasize.

In recent work, Shipitsin and coworkers [22] found that CD24 is expressed on more differentiated cells whereas CD44 is expressed on more progenitor-like cells. Specifically, they found that breast cells of the CD44+/CD24- phenotype express genes that are involved in cell motility and angiogenesis, are more mesenchymal, are motile, and are predominately estrogen receptor negative. In agreement with this study, we and others have also observed a strong association between breast cancer cells with a basal-like or mesenchymal-like phenotype (MDA.MB.231, SUM159, SUM1315) and the presence CD44+/CD24- cells (unpublished data, [21]). In contrast, cells with a more luminal, epithelial appearance (MCF7 and SUM225) were largely CD44\% $\mathrm{CD}_{24}{ }^{+}$, which is consistent with the luminal differentiated mucin-1-positive, estrogen receptor/progesterone receptorpositive, Gata3-positive cells reported by Shipitsin and coworkers. Taken together, these studies suggest another 
interesting interpretation of CD24 and CD44 as markers of breast cancer cells; perhaps CD44+ cells are predominately basal-like and therefore are present in poor prognosis basallike tumors, whereas $\mathrm{CD}_{2} 4^{+}$cells are luminal-like and therefore present in more differentiated luminal-type cancers.

\section{Conclusion}

With the aim being to eradicate breast cancer, there is great interest and excitement in the possibility of identifying and treating the subpopulation of cancer stem cells that fuel tumor growth. However, there remains a need to determine whether CD44 ${ }^{+}$CD24- cells are true tumorigenic cells across all the various breast cancer subtypes, or whether these are unique to a more basal tumor type. Fortunately, the field is growing with the identification of new potential markers, such as protein C receptor [20], which may permit further enrichment and identification of therapeutic targets for treatment of breast cancer.

\section{Competing interests}

The authors declare that they have no competing interests.

\section{Acknowledgements}

We should like to thank the Susan Komen Foundation and the Breast Cancer Research Foundation. CK is a Raymond and Beverly Sackler Foundation Scholar.

\section{References}

1. Lapidot T, Sirard C, Vormoor J, Murdoch B, Hoang T, CaceresCortes J, Minden M, Paterson B, Caligiuri MA, Dick JE: A cell initiating human acute myeloid leukemia after transplantation in SCID mice. Nature 1994, 367:645-648.

2. Al-Hajj M, Wicha SM, Benito-Hernandez A, Morrison SJ, Clarke MF: Prospective identification of tumorigenic breast cancer cells. Proc Natl Acad Sci USA 2003, 100:3983-3988.

3. Shackleton M, Vaillant F, Simpson KJ, Stingl J, Smyth GK, Asselin-Labat ML, Wu L, Lindeman GJ, Visvader JE: Generation of a functional mammary gland from a single stem cell. Nature 2006, 439:84-88.

4. Stingl J, Eirew P, Richetson I, Shackleton M, Vaillant R, Choi D, Li $\mathrm{HI}$, Eaves CJ: Purification and unique properties of mammary epithelial stem cells. Nature 2006, 439:993-997.

5. O'Brien CA, Pollet A, Gallinger S, Dick JE: A human colon caner cell capable of initiating tumour growth in immunodeficient mice. Nature 2007, 445:106-110.

6. Collins AT, Berry PA, Hyde C, Stower MJ, Maitland NJ: Prospective identification of tumorigenic prostate cancer stem cells. Cancer Res 2005, 65:10946-10951.

7. Li C, Heidt DG, Dalerba P, Burant CF, Zhang L, Adsay V, Wicha M, Clarke M, Simeone DM: Identification of pancreatic cancer stem cells. Cancer Res 2007, 67:1030-1037.

8. Singh SK, Hawkins C, Clarke ID, Squire JA, Bayani J, Hide T, Henkelman RM, Cusimano MD, Dirks PB: Identification of human brain tumour initiating cells. Nature 2004, 432:396401.

9. Gudjonsson T, Villadsen R, Nielsen HL, Ronnov-Jessen L, Bissel $\mathrm{MJ}$, Petersen OW: Isolation, immortalization, and characterization of a human breast epithelial cell line with stem cell properties. Genes Dev 2002, 16:693-706.

10. Baumann P, Cremers N, Kroese F, Orend G, Chiquet-Ehrismann $\mathrm{R}$, Uede T, Yagita H, Sleeman JP: CD24 expression causes the acquisition of multiple cellular properties associated with tumor growth and metastasis. Cancer Res 2005, 23:1078310793.

11. Gunthert U, Hofmann M, Rudy W, Reber S, Zoller M, Haussmann I, Matzku S, Wenzel A, Ponta H, Herrlich P: A new variant of glucoprotein CD44 confers metastasis potential to rat carcinoma cells. Cell 1991, 65:13-24.
12. Hebbard L, Steffen A, Zawadski V, Fieber C, Howells N, Moll J, Ponta H, Hofmann M, Sleeman J: CD44 expression and regulation during mammary gland development and function. $J$ Cell Sci 2000, 113:2619-2630.

13. Osta WA, Chen Y, Mikhitarian K, Mitas M, Salem M, Hannun YA, Cole DJ, Gillanders WE: EpCAM is overexpressed in breast cancer and is a potential target for breast cancer gene therapy. Cancer Res 2004, 64:5818-5824.

14. Krause DS, Lazarides K, von Andrian UH, Van Etten RA: Requirement for CD44 in homing and engraftment of BCR-ABLexpressing leukemic stem cells. Nat Med 2006, 12: 1175-1180.

15. Parmar H, Young P, Emerman JT, Neve RM, Dairkee S, Cunha GR: A novel method for growing human breast epithelium in vivo using mouse and human mammary fibroblasts. Endocrinology 2002, 143:4886-4896.

16. Kuperwasser C, Chavarria T, Wu M, Magrane G, Gray JW, Carey L, Richardson A, Weinberg RA: Reconstruction of functionally normal and malignant human breast tissues in mice. Proc Natl Acad Sci USA 2004, 101:4966-4971.

17. Prioa DA, Kuperwasser C: Reconstruction of human mammary tissues in a mouse model. Nat Protoc 2006, 1:206-214.

18. Elenbaas B, Spirio L, Koerner F, Fleming MD, Zimonjic DB, Donaher JL, Popescu NC, Hahn WC, Weinberg RA: Human breast cancer cells generated by oncogenic transformation of primary mammary epithelial cells. Genes Dev 2001, 15:50-65.

19. Orimo A, Gupta PB, Sgroi DC, Arenzana-Seisdedos F, Delaunay T, Naeem R, Carey VJ, Richardson AL, Weinberg RA: Stromal fibroblasts present in invasive human breast carcinomas promote tumor growth and angiogenesis through elevated SDF-1/CXCL12 secretion. Cell 2005, 121:335-348.

20. Abraham BK, Fritz P, McClellan M, Hauptvogel P, Athelogou M, Brauch J: Prevalence of $\mathrm{CD} 44^{+} / \mathrm{CD} 24^{-/ \text {low }}$ cells in breast cancer may not be associated with clinical outcome but may favor distant metastasis. Clin Cancer Res 2005, 11:11541159.

21. Sheridan C, Kishimoto H, Fuchs RK, Mehrotra S, Bhat-Nakshatri $\mathrm{P}$, Turner $\mathrm{CH}$, Goulet R Jr, Badve S, Nakshatri H: CD44+/CD24 breast cancer cells exhibit enhanced invasive properties, an early step necessary for metastasis. Breast Cancer Res 2006, 8:R59.

22. Shipitsin M, Campbell LL, Argani $P$, Weremowicz S, BloushtainQimron N, Yao J, Nikolskaya T, Serebryiskaya T, Beroukhim R, Hu $\mathrm{M}$, et al.: Molecular definition of breast tumor heterogeneity. Cancer Cell 2007, 11:259-273. 